\title{
Bird protection in \\ Western Samoa
}

\author{
M.D. Merlin and J.O. Juvik
}

In a study supported by the FFPS Oryx $100 \%$ Fund, the authors investigated the impact of traditional hunting practices on native land birds in Samoa. Hunting and habitat modification have contributed to the near extinction of several endemic species. Through new hunting regulations, conservation education programmes and the development of a national park system, the Government of Western Samoa has moved to strengthen its commitment to the conservation of a unique insular biota.

Like most remote oceanic islands of the South Pacific, the Samoan archipelago has relatively few animal species in comparison with adjacent continental regions of similar size and environmental diversity. Land birds compose the major element in the native vertebrate fauna. Endemism is high, with 31 ( 84 per cent) of the 37 native species restricted to the Samoan archipelago (Muse and Muse, 1982).

Unfortunately, there is a lack of detailed data concerning the life histories and status of this unique avifauna. This is particularly distressing because the continued existence of some of Samoa's endemic birds is threatened by commercial forestry and hunting. For example, the population size of manumea, the extraordinary toothbilled pigeon Didunculus strigirostris, belonging to a genus endemic to Western Samoa, has been dramatically reduced because of ' . . hunting pressures and habitat destruction' (Ollier et al., 1979).

This paper reviews the literature dealing with the Samoan avifauna and presents the results of our Bird protection in Western Samoa observations of human-bird relationships collected on a visit to Samoa during July-August 1980. We carried out field-work on various parts of three islands: Savai'i, 'Upolu and Manono. We made surveys of both lowland and upland environments, particularly in areas proposed for, or already incorporated into, the newly-developed national parks' system. In addition, local people provided considerable information on birdhunting activities.

\section{Geographical outline}

Centred approximately $14^{\circ} \mathrm{S}$ of the equator and $600 \mathrm{~km}$ east of Fiji, the 14 volcanic islands of the Samoan chain are spread out $450 \mathrm{~km}$ along a north-west-south-east axis. Politically the archipelago is split into two groups: Western Samoa, an independent nation since 1962, composed of Savi'i, 'Upolu and their small outliers; and American Samoa, a US territory, which includes Tutuila and the Manu'a Islands.

Western Samoa includes the two largest islands in the archipelago; Savai'i (1820 sq km), with mountains rising to $1858 \mathrm{~m}$, and 'Upolu (1114 sq $\mathrm{km})$, with elevations to $1099 \mathrm{~m}$. Together they account for 93 per cent of the total land area of the chain and support the bulk of the native avifauna. Savai'i has experienced recent volcanic activity and is thus characterised by extensive, gently sloping, lava plains, few perennial streams, dispersed human settlement, and relatively large tracts of undisturbed tropical rain forest (Watling, 1982). 'Upolu is older, with more erosional dissection, better-developed soils, and surface water resources supporting higher human populations. Of the approximately 170,000 Western Samoans, about 120,000 reside on 'Upolu, both 


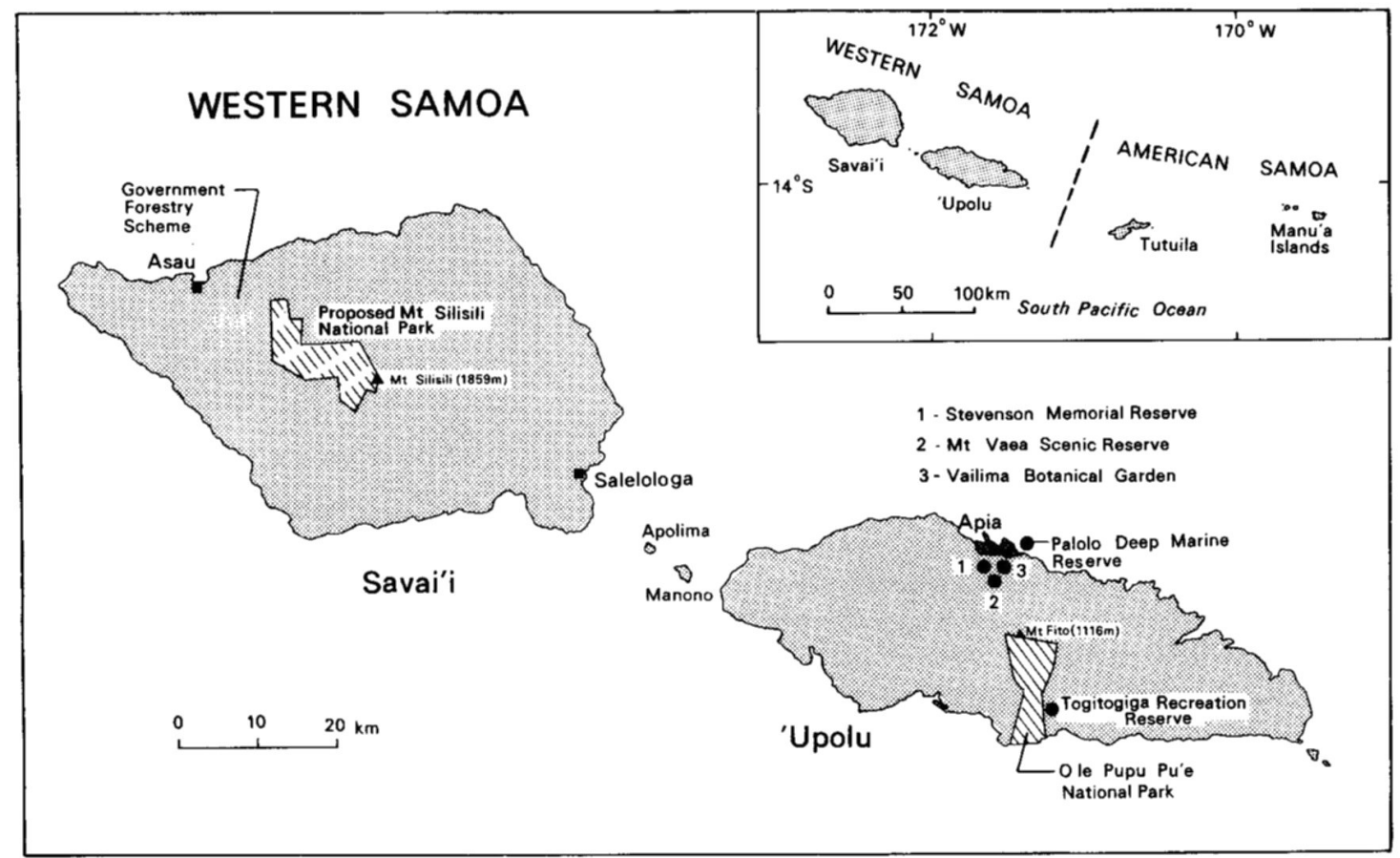

Figure 1. National Park and Reserve areas in Westem Samoa.

in the urban areas around Apia (the capital) and in smaller coastal villages. The greater density of human settlement on 'Upolu has resulted in more substantial degradation of the native forests than on Savai'i.

\section{Land birds}

Among the 37 native land bird species and subspecies in the Samoan archipelago, six are wideranging and occur in other Pacific island areas. The remaining 31 are endemic to the Samoan islands, with five forms restricted to the islands of American Samoa, a further 10 are found in both political jurisdictions and 16 species are restricted to 'Upolu and Savai'i in Western Samoa (Armstrong, 1932; Ashmole, 1963; Dupont, 1976; Kennedy, 1974). Those endemics considered to be threatened because of hunting and habitat destruction in Western Samoa are listed in Table 1. In addition to the native avifauna, at least four species of introduced land birds have established breeding populations: moa'ai vao, the jungle fowl Gallus gallus, presumably introduced in the prehistoric period; the red-vented bulbul Pycnonotus cafer bengalensis; jungle mynah Acridotheres fuscus; and rock dove Columba 98 livia, which became established during this century.

\section{Bird hunting}

Several species, especially the native pigeons and doves, are hunted for food and sport. Indeed, the relatively large number of Samoan proverbs involving bird hunting indicates that some species have long served as a significant source of meat (Schultz, 1965). In addition, the recreational exploitation of the avifauna is an ancient Samoan pastime. The French navigator, Louis Antoine de Bougainville, noted in 1772 , in the earliest recorded reference to the birds of Samoa, that people 'amuse themselves in their leisure hours by taming birds' and that their houses 'were full of wood-pigeons, and they bartered them by the hundreds' (Armstrong, 1932).

Undoubtedly, exploitation of the Samoan avifauna began early in the prehistoric phase of human occupation. This assumption is supported by archaeological evidence from a number of other Pacific islands, where the record of Polynesian extirpation of numerous flightless bird species is well documented (the extinction of the 
New Zealand Moa fauna being the most dramatic). A recent analysis of fossil deposits found in the Hawaiian Islands suggests that 50 per cent or more of the native avifauna were extirpated prior to European contact and that much of this loss was the result of clearing lowland forests and hunting by early Polynesian settlers (Olson and James, 1982). Although comparable palaeontological/archaeological finds have not yet been discovered in Samoa, it is probable that an early wave of avian extinctions followed Polynesian settlement some 3000 years ago.

In the historic period a number of traditional methods of Samoan bird hunting have been well documented. Coconut-fibre snares were often used to trap sega vao, the blue-crowned lory Vini australis. The attractive blue and red feathers of this small indigenous bird were incorporated into ceremonial costumes and fine mats ('ie tōga). Today these special costumes and mats are often decorated with dyed chicken feathers. Another ancient method involved the use of contained decoys to lure wild individuals into a cage trap. Now only manutagi, the crimson-crowned fruit dove Ptilinopus porphyraceus fasciatus is still captured in this way. According to Samoan legend describing a pigeon-snaring contest, a captured bird was tethered and used to lure flocks of pigeons within range of trapping nets. These nets were attached to long poles that were rapidly swept back and forth when the pigeons flew down near the decoy (Herman, 1955). Nets were also supposedly used to catch the now presumed extinct, flightless puna'e, or Samoan wood rail Pareudiastes pacificus. This species, belonging to an endemic monotypic genus, was last seen for certain on Savai'i in 1874 (Yaldwyn, 1952). Bows and arrows with one or more prongs were used to catch ve'a, the banded rail Rallus philippensis goodsoni, a common groundfeeding bird. In order to get close enough to the secretive rails, some hunters would hide inside small huts and wait for the birds to come within range of their weapons (Schultz, 1955).

Sling-shots are commonly used today to stun or kill small native land birds such as the bluecrowned lory; segasega mau'u or cardinal honeyeater Myzomela cardinalis nigriventris; and 'iao, the wattled honeyeater Foulehaio caruncu-

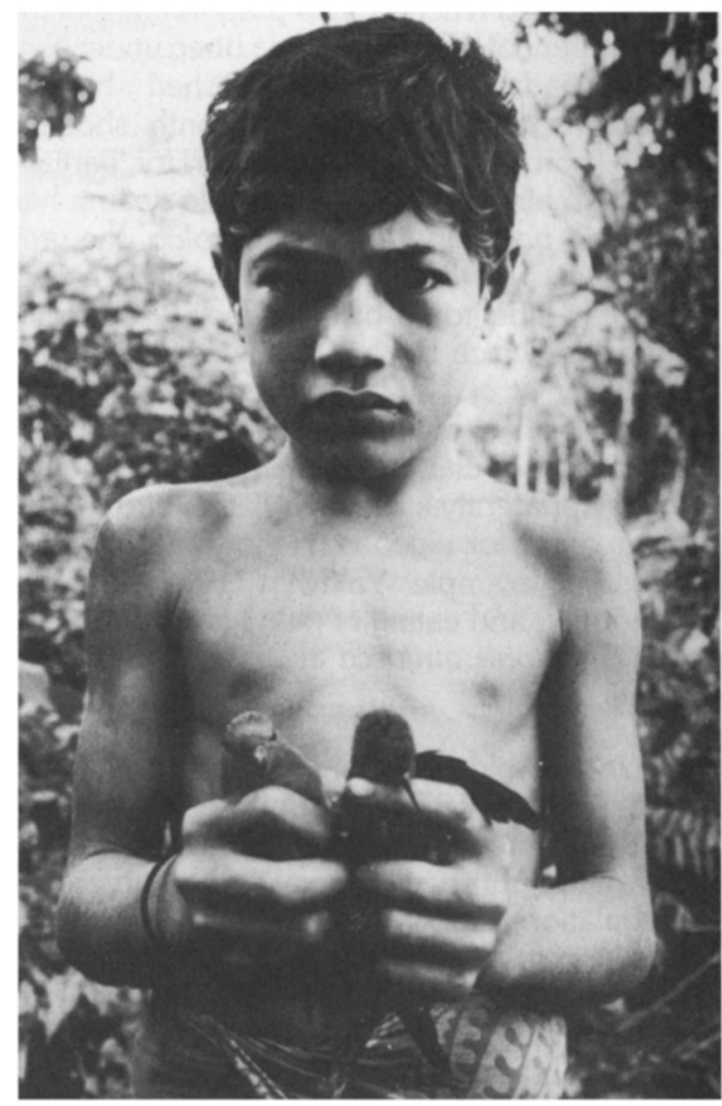

A young Samoan displays the fruits of his slingshot hunting at Asau Savai'i: a blue-crowned lory (left) and a cardinal honeyeater (right), both taken for food.

lata carunculata. Boys and young men stalk their prey near the coast under large flowering trees (for example, Erythrina spp. and Sygyzium sp.) on which the birds come to feed. We observed this activity frequently near the village of Asau on the north-west coast of Savai'i. We also saw, in other villages on Savai'i, young children holding small birds whose feathers had been plucked. We were told that lories and honeyeaters were commonly eaten by the younger Samoans, but birds are also sometimes kept as pets. Although widespread hunting with sling-shots may have some impact on the land birds, it certainly does not pose as significant a threat as does the contemporary, widespread use of guns.

\section{Government hunting regulations}

By 1983 the impact of bird hunting, especially 
with guns, had reached such proportions that the Government of Western Samoa (then under New Zealand administration) established hunting regulations, designating a six-month shooting season (from 1 July to 31 December) for 'partially protected' birds: manuali'i or purple swamp hen Porphyrio porphyrio samoensis; toloa, the grey duck Anas superciliosa; and all pigeons, except manumea, the tooth-billed pigeon Didunculus strigirostris, which by that time was fully protected. (Ollier et al., 1979). Nevertheless, "pigeon hunting' with shotguns continued to be widespread and popular throughout the year and the hunters apparently killed many other bird species in their quest for pigeons (Holloway and Floyd, 1975). For example, Yaldwyn (1952) reported the shooting and eating of many fuia or Samoan starlings Aplonis atrifusca at Vaipouli, Savai'i in the early 1950s.

In 1976 the old bird hunting regulations were revoked and in 1978, in response to a request from the Prime Minister of Western Samoa, the Office of the Attorney-General drafted a proposal for regulations that would provide partial protection for some wild bird species under section 41 of the Animal Ordinance of 1960. The original 1978 draft ordinance contained a mixture of very common and very rare species, which were all to be given only partial protection (none of the seven listed could be taken or killed anywhere in Western Samoa between 1 November and 30 June of any year). During revision of the 1978 draft it was proposed that some species deserved complete protection. The three species to be given partial protection were: lupe or Pacific pigeon Ducula pacifica pacifica, found throughout the south-west Pacific; fiaui or white-throated pigeon Columba vitiensis castaneiceps, a subspecies endemic to Western Samoa; and manutagi or crimson-crowned fruit dove Ptilinopus porphyraceus fasciatus, a subspecies endemic to both Western and American Samoa. Although these three birds have been hunted traditionally in Western Samoa, all are still common throughout the country and none is in danger of extinction. Nonetheless, excessive hunting could significantly reduce their population sizes, and it was suggested that hunting of these species be restricted to September and October to avoid their peak breeding period, which is believed to occur between May and August.

The revised draft listed 12 species of native birds considered to be rare, threatened or endangered in Western Samoa as deserving 'absolute protection'. It was pointed out that if any of these species were hunted they 'would almost certainly become extinct in the very near future' (Ollier et al., 1979).

There were also recommendations regarding the effective enforcement of the proposed regulations, including the confiscation of guns and game from violators and imposition of appropriate fines. It took more than two years before recommendations in the revised draft were incorporated into legislation and during this period hunting apparently did not decline. When we visited Savai' $i$ in August 1980, we observed young men carrying shotguns into the forests of the largest island and were told that bird hunting occurred throughout the year.

Finally, on 17 January 1981, pursuant to section 41 of the Animals Ordinance 1960. I, Malietoa Tanumafili II, the Head of State of Western Samoa, signed into law the Animals (Protection of Wild Birds) Regulations 1981. Following the recommendations suggested in the revised proposal of 1978 , the Pacific pigeon, whitethroated pigeon and crimson-crowned fruit dove were all declared to be partially protected, but the hunting season for these species was lengthened to extend from 1 November to 31 March. A total of 16 species and subspecies were declared to be absolutely protected; only the Samoan wood rail, which has not been officially recorded for over 100 years and is presumed extinct, was dropped from the list. The 1981 regulations added four species not recommended in the 1978 proposal: the cardinal honeyeater; blue-crowned lory; kingfisher or ti'otala Halcyon recurvirostris; and the red robin broadbill or tolai ula, for which the scientific name was not given. This could lead to some confusion since at least two birds in Western Samoa (Samoan broadbill Myiagra albiventris and scarlet robin Petroica multicolor) are both referred to as tolai 'ula (Armstrong, 1932; Muse and Muse, 1982; Watling, 1982). The 'absolutely protected' list includes all of the most severely 
Table 1. Absolutely and partially protected bird species of Western Samoa*

\begin{tabular}{|c|c|c|c|}
\hline Species & English name & Samoan name & $\begin{array}{l}\text { Protection } \\
\text { status }\end{array}$ \\
\hline Ptilinopus porphyraceus fasciatus & crimson-crowned fruit dove & Manutagi & Partial \\
\hline Ducula pacifica pacifica & Pacific pigeon & Lupe & Partial \\
\hline Columba vitiensis castaneiceps & white-throated pigeon & Fiaui & Partial \\
\hline Anas superciliosa & grey duck & Toloa & Absolute \\
\hline Porzana tabuensis tabuensis & sooty rail & not known & Absolute \\
\hline Poliolimnas cinereus tannensis & white-browed rail & Vai & Absolute \\
\hline Ptilinopus perousii perousii & many-coloured fruit dove & Manuma & Absolute \\
\hline Gallicolumba stairi stairi & friendly ground-dove & $\begin{array}{l}\text { Tu'aimeo (female) } \\
\text { Tutautifa (male) }\end{array}$ & Absolute \\
\hline Didunculus strigirostris & Samoan tooth-billed pigeon & Manumea & Absolute \\
\hline Vini australis & blue-crowned lory & Sega Vao & Absolute \\
\hline Halcyon recurvisrostris & flat-billed kingfisher & Ti'otala & Absolute \\
\hline $\begin{array}{l}\text { Lalage sharpei sharpei } \\
\text { and } L . s \text {. tenebrosa }\end{array}$ & Polynesian triller & Miti & Absolute \\
\hline Turdus poliocephalus samoensis & island thrush & Tutumalili & Absolute \\
\hline Zosterops samoensis & Samoan white-eye & not known & Absolute \\
\hline Gymnomyza samoensis & mao or ma'oma'o & Ma'oma'o & Absolute \\
\hline Myzomela cardinalis nigriventris & cardinal honeyeater & Segasega Mau'u & Absolute \\
\hline $\begin{array}{l}\text { Erythura cyaneovirens cyaneovirens } \\
\text { and E. c. gaughrani }\end{array}$ & red-headed parrot finch & Manu'aipa'u la'ua & Absolute \\
\hline ? scientific name uncertain & 'Red robin broadbill' & 'Tolai ula' & Absolute \\
\hline
\end{tabular}

*Officially covered under the Wild Bird Protection Regulation, 1981.

Protection status: partially protected species may be hunted from November 1 to March 31 only; absolutely protected species cannot be trapped or hunted at any time.

threatened Samoan species including the toothbilled pigeon and giant honeyeater or mao, which have all but disappeared from 'Upolu (though still present on Savai'i), and the Samoan white-eye, restricted in range to the small montane forest area on Savai'i.

Although there are some apparent omissions and misspellings in the list, we can only hope that the regulations will be enforced by the Department of Agriculture, Forests, and Fisheries. Muse and Muse (1982) have, however, pointed out that since Samoans have long been accustomed to hunting birds for food and recreation, it will be very difficult to force a change.

A number of other factors contribute to the decline of some native bird species: the clearing of forests; the impact of introduced mammalian predators such as feral cats; and the use of pesticides. Nevertheless, it has been argued that even though hunting is not the only reason for bird population decline, 'in the case of species already on the verge of extinction from loss of habitat or forms of environmental degradation, it could Bird protection in Western Samoa make the difference between partial recovery and total extinction' (Holloway and Floyd, 1975).

\section{National parks and reserves}

Habitat deterioration resulting from a rapidly expanding human population within a limited land area has severely threatened the integrity of the natural ecosystem. Recognising the need to protect representative natural environments as reserves for wildlife, watersheds, and for recreation and tourism, the Samoan Government passed a National Parks and Reserves Act in 1974. Major studies were undertaken to assess conservation strategy and the feasibility of developing a national park system (Holloway and Floyd, 1975; Ollier et al., 1979).

A problem confronting park development is the traditional land tenure system. Over 80 per cent of the land is under 'customary' ownership, that is land (usually strips running from the coast to the mountains) held communally by village clans. It is extremely difficult for the Government to alienate 
such land even for 'public' use. While many other Polynesian societies have collapsed or been inundated by more recent immigrant groups, Samoans clearly perceive that the current strength and vitality of their traditional culture has been closely tied to tenacious control of their land at village level. Thus, with respect to national park development, the Government is constrained politically to work with those few areas under government ownership or to acquire 'wasteland' areas such as recent volcanic lava flows where there are few exploitable resources and thus no strong claims of customary ownership.

In 1978 the first national park was established on 'Upolu. Covering more than 2830 ha, O Le Pupu-pu'e National Park runs from the coast to the summit of the island's main mountain ridge, incorporating Mt Fito $(1116 \mathrm{~m})$ and several distinct ecological zones. The park is more or less congruent with the geologically young basaltic lavas which were erupted from Mt Fito approximately 3000 years ago. While the area is well forested, it is generally perceived to have little agricultural value. Hence there were few local objections to designating this area a national park. Several other, smaller, specialised nature reserves have been established on 'Upolu, including the Palolo Deep Marine Reserve near Apia, and botanical gardens and scenic reserve surrounding Mt Vaea, where Robert Louis Stevenson is buried.

The O Le Pupu-pu'e National Park contains a fairly diverse representation of native avifauna, although some of the most threatened species, for example the tooth-billed pigeon, have not been recently recorded there. It is unlikely that this park alone will be able to ensure long-term survival of the 'Upolu forest birds if the remaining adjacent mountain forests continue to be degraded or converted to commercial forestry and agriculture. Although the park is an impressive start, particularly for a small, Third World nation struggling for economic and social development, the ultimate fate of the Samoan avifauna will probably rest with long-term land use decisions made on the larger island of Savai'i. A national park has been proposed for central Savai'i, incorporating Mt Silisili (1859 $\mathrm{m}$ ) and adjacent areas covered by the partially revegetated, 200-year-old A'opo lava flow (Holloway and Floyd, 1975). Again, this 102

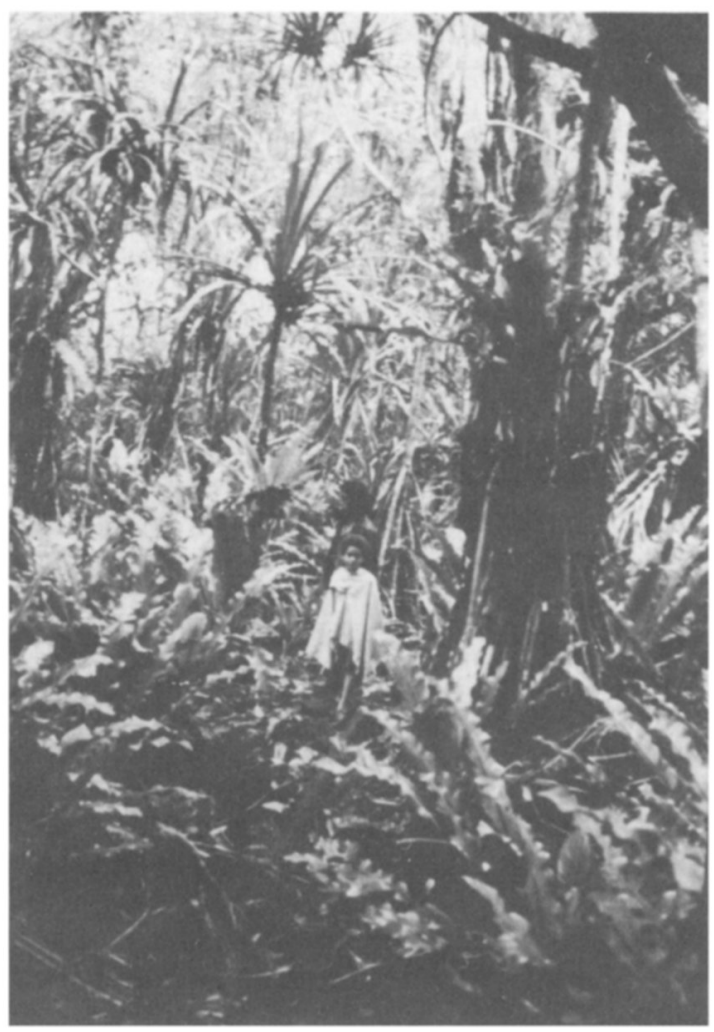

Undisturbed coastal rain forest (Pandanus spp. dominant) in O Le Pupu-pu'e National Park.

area has been proposed both for its intrinsic ecological value and because the locally perceived 'wasteland status' of volcanic terrain improves the political feasibility of park development. As long as 'lava flow parks' incorporate some adjacent mature rain forest as seed source areas, natural succession will eventually produce diverse natural climax forests. The habitat diversity associated with the successional continuum should support a great range of wildlife.

A major long-term threat to the native avifauna on Savai'i results from the large-scale development of commercial forestry, involving the cutting of hardwoods and replanting with exotics such as teak and mahogany. Exotic forests tend to exclude specialised endemic birds and present other hazards. For example, in September 1983 a massive forest fire bumed across much of western Savai'i, laying waste to thousands of hectares of

Oryx Vol 19 No 2 


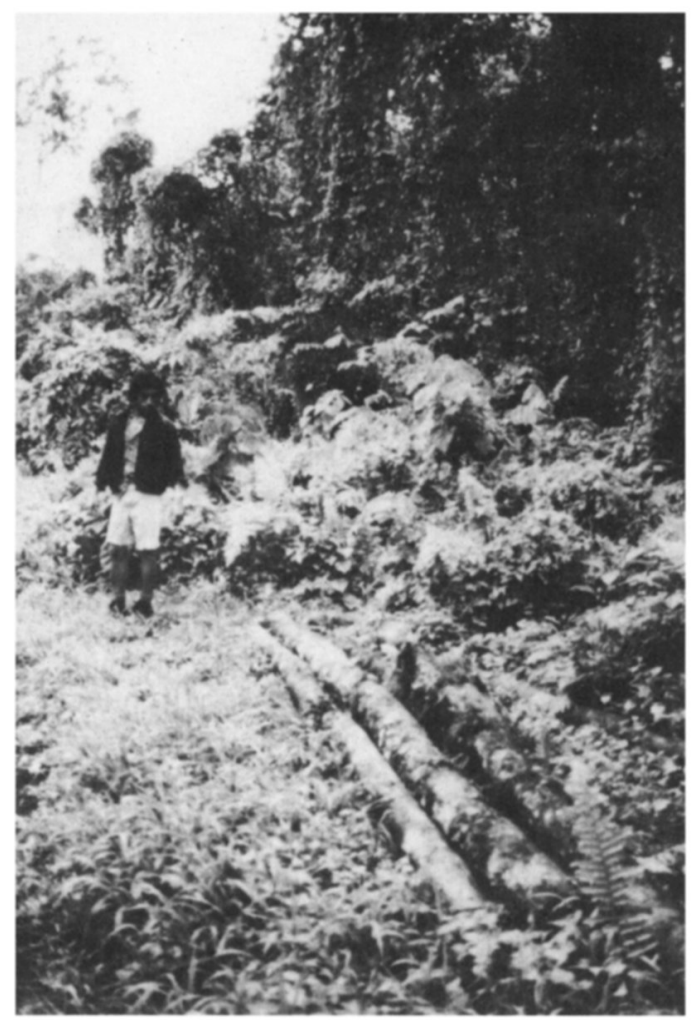

O Le Pupu-pu'e National Park. Park supervisor, Joseph Lee, inspects trees cut illegally for traditional house poles.

both native and commercial forests. Because many of Samoa's threatened land birds are on the verge of local extinction on 'Upolu, the need to establish substantial reserves on Savai'i is essential, but at the same time is problematic in the face of competing economic development priorities.

\section{Conclusions}

Even after three millenia of human settlement, the Samoan islands still support a diverse and unique avifauna of great evolutionary significance. The Western Samoan Government has moved to protect native wildlife through hunting regulations and a national park and reserve programme. Perhaps more importantly, a conservation education programme has also been instituted to modify attitudes towards traditional resource exploitation. The long-term survival of the local avifauna will depend upon better enforcement of hunting regulations and the creation of substantially more forest reserve and park areas (particularly on Savai'i). It is unlikely that Western Samoa will be able to achieve this goal without international support since pressure for commercial development of forest lands is based on valid economic objectives in a relatively resource-poor nation.

\section{Acknowledgments}

We would like to thank Rex Mossman (New Zealand advisor) and Joseph Lee of the Department of Agriculture and Forests (Western Samoa) for their assistance and logistic support on 'Upolu.

\section{References}

Armstrong, J.S. 1932. Hand-list to the Birds of Samoa. John Bale, Sons \& Danielsson, London.

Ashmole, M.J. 1963. Guide to the Birds of Samoa. Pacific Science Information Center, Bernice P. Bishop Museum, Honolulu, Hawaii.

Dupont, J.E. 1976. South Pacific Birds. Delaware Museum of Natural History, Greenville, Delaware.

Herman, B. 1955. Tala O Le Vavau, Samoan Legends. The Association of Marist Brothers' Old Boys, Pago Pago, American Samoa.

Holloway, C.W. and Floyd, C.H. 1975. A national park system for Westem Samoa. Report for United Nations Development Advisory Team for South Pacific (UNDAT), Suva, Fiji, 45 pp. plus appendices.

Kennedy, T.F. 1974. A Descriptive Atlas of the Pacific Islands. Reed Education, Wellington, New Zealand.

Muse, C. and Muse, S. 1982. The Birds and Birdlore of Samoa. Pioneer Press, Walla Walla, Washington

Ollier, C.D., Whistler, W.A. and Amerson (Jr) A.B. 1979. O Lè Pupu-Pu'e National Park, Samoa. Vol. 2, Report for United Nations Development Advisory Team for the South Pacific (UNDAT), Suva, Fiji.

Olson, S.L. and James, H.F. 1982. Prodromus of the fossil avifauna of the Hawaiian Islands. Smithson. Contr. Zool., No. 365, Smithsonian Institution Press, Washington, D.C.

Schultz, E. 1965. Proverbial expressions of the Samoans. The Polynesian Society, Wellington, New Zealand.

Watling, D. 1982. Birds of Fiji, Tonga and Samoa. Milwood Press, Wellington, New Zealand.

Yaldwyn, J.C. 1952. Notes on the present status of Samoan birds. Notornis, 5, 28-30.

M.D. Merlin, Department of General Science, University of Hawaii at Manoa, Honolulu, Hawaii 96822, USA

J.O. Juvik, Department of Geography, University of Hawaii at Hilo, Hilo, Hawaii 96720 , USA 